\title{
The influence of light quality on phenolic acid and biflavonoid production in Anacardium othonianum Rizz. seedlings grown in vitro
}

\author{
Ana Paula Gazolla ${ }^{1}$, Flávia Maria Lígia Marangoni Jordão Curado ${ }^{2}$, Rita Cássia Nascimento \\ Pedroso $^{2}$, Luis Claudio Kellner Filho ${ }^{2}$, Juliana de Fátima Sales ${ }^{1}$, Márcio Rosa ${ }^{3}$, Alan Carlos Costa ${ }^{1}$, \\ Patricia Mendonça Pauletti ${ }^{2}$, Ana Helena Januário ${ }^{2}$, Fabiano Guimarães Silva ${ }^{{ }^{*}}$
}

${ }^{1}$ Plant Tissue Culture Laboratory, Federal Institute of Education, Science and Technology Goiano - Rio Verde. Rodovia Sul Goiana, km 1-Zona Rural, CEP 75901-970, Rio Verde, Goiás, Brazil

${ }^{2}$ Center for Research in Exact and Technological Sciences, University of Franca, Av. Dr. Armando Salles de Oliveira, 201, CEP 14404-600, Franca, São Paulo, Brazil

${ }^{3}$ University of Rio Verde - UniRV, Rio Verde Campus, Fontes do Saber farm, Cx. P. 104. CEP: 75901-970, Rio Verde - Goiás, Brazil

\section{*CorrespondingAuthor:fabianoifgoiano@gmail.com}

\begin{abstract}
Anacardium othonianum Rizz., popularly known as the Cerrado cashew tree, is widely used in medicine due to its therapeutic properties, including its antioxidant, anti-inflammatory, and antidiarrheal activities. Light is an important regulator of the growth, development of plants differentiation, and metabolism. Considering the influence of light on the production of phytochemicals, the aim of the present study was to evaluate production of gallic and 3,4-dihydroxybenzoic acids and amentoflavone in A. othonianum seedlings grown in vitro exposure to white, blue, green, red, and yellow light. The seedlings were evaluated with respect to the length of the aerial parts and the number of leaves, at 0,20 , and 40 days of treatment. The fresh and dry weights of the aerial parts and the levels of phenolic acid and biflavonoid were evaluated at 40 days via high-performance liquid chromatography with a diode array detector (HPLC-DAD). Regardless of the light wavelength used for the growth, the largest length of the aerial parts $(5.54 \mathrm{~cm})$ and an increase in the number of leaves (2.86-fold) were observed at 40 days. The largest accumulations of fresh weight (325.5 mg and $335.1 \mathrm{mg}$ per seedling) and dry weight $(83.3 \mathrm{mg}$ and $84.5 \mathrm{mg}$ per seedling) were observed in seedlings grown under red and yellow light, respectively. Relatively higher levels of gallic acid $\left(0.66 \mathrm{mg} \cdot \mathrm{g}^{-1}\right.$ dry weight $)$ and amentoflavone $\left(1.41 \mathrm{mg} . \mathrm{g}^{-1} \mathrm{dry}\right.$ weight $)$ were found in seedlings grown under blue light. In contrast, the 3,4-dihydroxybenzoic acid levels of the seedlings under red light increased (8.22 mg.g $\mathrm{g}^{-1}$ dry weight).
\end{abstract}

Keywords: Anacardiaceae, biflavonoid, biometric characteristics, light quality, phenolic acids, tissue culture. Abbrevations:ANOVA_analysis of variance, BAP_6-benzylaminopurine; DW_dry weight; FW_fresh weight; HPLC-DAD_highperformance liquid chromatography with a diode array detector; mg_milligrams; MS_Murashige and Skoog.

\section{Introduction}

Anacardium othonianum Rizz. (Anacardiaceae) is a fruit plant native to Brazilian Savannah in the Central Region of Brazil. It is popularly known as the cashew tree of the Cerrado (Silva et al., 2001, Agostini-Costa et al., 2006). This species is widely used in popular medicine. Tea made from its roots has purgative activity, and when macerated in wine, is used to treat diabetes and rheumatism. The bark has stimulating activity and is used for the treatment of sore throat. The leaves and bark have antidiarrheal and expectorant activities. The oil extracted from the seeds is used to eliminate blemishes and warts, and the pseudo fruits considered to be anti-syphilitic. The stalk is rich in vitamin C, fiber, and phenolic compounds. In addition to vitamin potential, these compounds confer an antioxidant potential to cashew pulp, which is associated with the prevention of chronic degenerative diseases such as cardiovascular disease, cancer and diabetes. The rate of these chronic diseases is ever-increasing and a cause of concern among healthcare professionals (Agostini-Costa et al., 2006).
The fruits and cashew (pseudo-fruit) of A. othonianum has high commercial value in the food industry; however, the slow growth of its seedlings has restricted its commercial cultivation to small producers and to extractivism (Vieira et al., 2006). The nutritional value of pseudo-fruits of $A$. othonianum is well-known (Silva et al., 2008; Bessa et al., 2013). Studies about the growth aspects of $A$. othonianum in related to the medium composition in in vitro culture have been developed by Bessa and co-authors (Bessa et al., 2013). Researches on associations of A. othonianum with endomycorrhizal and endophytic fungi have also been conducted to better understanding the growth influencing factors for this species (Faria et al., 2016).

Light is an important regulator of the growth and development of plants (Folta and Childers, 2008). Light primarily acts on plants via two mechanisms. First, the light source provides the energy required by the plant for photosynthesis. Second, light signals are captured by 
photoreceptors and regulate plant growth, differentiation and metabolism (Wang et al., 2001).

Specific responses are triggered by light in plants depending on the wavelength used. The blue light (400-500 $\mathrm{nm})$ controls phototropism, leaf growth, stem growth and anthocyanin accumulation. The red light $(660 \mathrm{~nm})$ controls germination, chloroplast function and stem and petiole growth. Both red and far red light influence flowering and gene expression (Carvalho and Folta, 2014).

The blue and red light are essential vital spectral bands for plants; violet, green, yellow, and orange lights confer minor benefits; and UV and far red light confer major benefits to plants (Liu, 2012). The quality of light decisively affects production of secondary metabolites in plants (Victório et al., 2015). The implementation of light quality strategies in tissue cultures can optimize the production of metabolites with therapeutic benefits. Accordingly, the determination of optimal spectral attributes is an important consideration for improving the growth and development of plants and optimizing the production of bioactive compounds (Odabas et al., 2009). To the best of our knowledge, there is no work in the literature about quality of light influencing seedlings at in vitro culture of species belong to Anacardium genus. Therefore, the present study aimed to evaluate the influence of the quality of light on the growth parameters and synthesis of gallic and 3,4-dyhidroxybenzoic acid and the biflavonoid amentoflavone in A. othonianum seedlings grown in vitro.

\section{Results}

Influence of light spectrum on composition of phytochemicals in plants environment

The white and blue light in growth environments provided the plants with a small amount of UV-A (330-400 nm). In these environments, the blue spectrum (400-490 nm) predominated. The green lights focused their emission in the green (490-560 nm) and yellow (560-590 nm) spectral regions (Table 1). In contrast, the red or yellow light environments provided the plants with a higher amount of light in the red spectrum $(600-700 \mathrm{~nm})$.

The average length of the aerial parts and the average number of expanded leaves were not influenced by the interaction of the light source in the period of evaluation. After 40 days of cultivation, the length of the aerial parts of the seedlings increased to $5.54 \mathrm{~cm}$, corresponding to a 1.7fold increase over those measured on the day of inoculation. With regard to the average number of expanded leaves, the highest values occurred at 20 and 40 days (2.46 and 2.86fold, respectively), corresponding to an increase of 1.45 and 1.70-fold, respectively (Table 2). The characteristics of the $A$. othonianum Rizz. seedlings treated for 0,20 , and 40 days are shown in Fig 3.

The fresh and dry weights observed in the seedlings grown in red and yellow light were higher than those grown in white light (control), with a proportional increase of 1.08 and 1.15fold, respectively. The results obtained using the other light spectra did not differ from each other (Table 3 ).

The calibration curves obtained for the gallic acid, 3,4dihydroxybenzoic acid, and amentoflavone standards showed correction coefficients $\left(R^{2}\right)$ of $0.998,0.9999$, and 0.9978, respectively. These curves allowed for the calculation of the levels of these compounds in the evaluated samples. The accumulation of gallic acid was negatively affected by yellow light treatment $\left(0.47 \mathrm{mg} \cdot \mathrm{g}^{-1} \mathrm{DW}\right)$. The levels of gallic acid found in the seedlings grown under green and red light did not differ from those of the seedlings grown under white light
(0.56, 0.58, and $0.55 \mathrm{mg} . \mathrm{g}^{-1} \mathrm{DW}$, respectively). The highest level of gallic acid was observed in the seedlings grown under blue light $\left(0.66 \mathrm{mg} \cdot \mathrm{g}^{-1} \mathrm{DW}\right)$ (Fig 4).

The highest average yields of gallic acid were found in the seedlings cultivated under blue $(0.16 \mu \mathrm{g}$ per seedling $)$ and red light $(0.14 \mu \mathrm{g}$ per seedling). The yields of the seedlings grown under green and yellow light did not differ, compared to control, with average values of $0.12,0.12$, and $0.13 \mu \mathrm{g}$ per seedling, respectively.

In contrast to gallic acid, the highest levels of 3,4dihydroxybenzoic acid, also known as protocatechuic acid, were found in the seedlings cultivated under red light (8.22 $\mathrm{mg} \cdot \mathrm{g}^{-1} \mathrm{DM}$ ), followed by those grown under white, blue, and yellow light, although the results for the three last spectra did not differ from one another or from those grown under green light (4.75 mg.g $\left.{ }^{-1} \mathrm{DW}\right)$ (Fig 4).

Similarly, the highest yield of 3,4-dihydroxybenzoic acid were achieved in the seedlings grown under red $(6.78 \mu \mathrm{g}$ per seedling) and blue light (5.57 $\mu \mathrm{g}$ per seedling). The average yield of the seedlings grown under green light $(3.53 \mu \mathrm{g}$ per seedling) was lower than that of the control (Fig 4).

As observed for gallic acid, the seedlings cultivated under blue light presented the highest levels of amentoflavone (1.41 mg.g ${ }^{-1}$ DW) (Fig 4). In contrast, the seedlings grown under green, red, and yellow light presented the lowest levels of amentoflavone $\left(0.61, \quad 0.69\right.$, and $0.63 \mathrm{mg}^{-1} \mathrm{gW}$, respectively) compared to the seedlings grown under white light.

Similar to the aforementioned concentration pattern, the seedlings grown under blue light produced relatively high yields of amentoflavone $(0.88 \mu \mathrm{g}$ per seedling). However, the yields of the seedlings grown under yellow or red light did not differ from those of seedlings grown under white light. The seedlings grown under green light presented the lowest yields of amentoflavone ( $0.34 \mu \mathrm{g}$ per seedling) (Fig 4).

\section{Discussion}

Light is an exogenous signal that induces several adaptive responses in plants (Wang et al., 2012). Macedo et al. (2011) found that blue light induced a higher number of leaves per plant, and red light triggered an increase in the fresh and dry weights of Alternanthera brasiliana Kuntze leaves. In the present study, we found an increase in the fresh and dry weights of A. othonianum seedlings grown under red and yellow light. However, none of the wavelengths employed in our study produced an increase in the number of leaves. In contrast, Nishimura et al. (2007) reported that plants cultivated under blue light increased the dry weight of Hypericum perforatum. However, this effect was obtained using an irradiance of $500 \mu \mathrm{mol} \cdot \mathrm{m}^{-2} \cdot \mathrm{s}^{-1}$, which is 10 times higher than that used in our study.

In their studies, Kvaalen and Appelgren (1999) showed that red light intensifies the germination of Picea abies (Norway spruce). Red light can also stimulate stolon formation in potato cultures in vitro, probably due to increased gibberellic acid biosynthesis (Vreugdenhil et al., 1998). However, red light increases cytokinin levels in germinating Pinus sylvestris seeds. Cytokinins are associated with the stimulation of phenolic compound synthesis (Jeong et al., 2007; Lee et al., 2010). Although green light may be related to the growth and synthesis of endogenous substances via cryptochrome-dependent and independent mechanisms (Folta and Childers, 2008; Bian et al., 2015). In the present study, the fresh and dry weight of the seedlings exposed to green light were lower than those of the seedlings treated under 
Table 1. Spectral composition of the light sources used.

\begin{tabular}{lccccc}
\hline \multirow{2}{*}{$\begin{array}{l}\text { Cultivation } \\
\text { environment }\end{array}$} & \multicolumn{5}{c}{ Spectral composition (\%) } \\
\cline { 2 - 6 } & UV-A & $\begin{array}{c}\text { Blue } \\
(330-400 \mathrm{~nm})\end{array}$ & $\begin{array}{c}\text { Green } \\
(490-560 \mathrm{~nm})\end{array}$ & $\begin{array}{c}\text { Red } \\
(600-700 \mathrm{~nm})\end{array}$ & $\begin{array}{c}\text { Far red } \\
(700-750 \mathrm{~nm})\end{array}$ \\
\hline White & 3.13 & 29.27 & 26.70 & 18.00 & 1.21 \\
Blue & 4.65 & 84.45 & 5.20 & 0.02 & 0.01 \\
Green & 0 & 1.88 & 68.77 & 8.13 & 0 \\
Red & 0 & 0.09 & 1.77 & 85.14 & 0.61 \\
Yellow & 0 & 0.21 & 16.09 & 42.66 & 0.90 \\
\hline
\end{tabular}

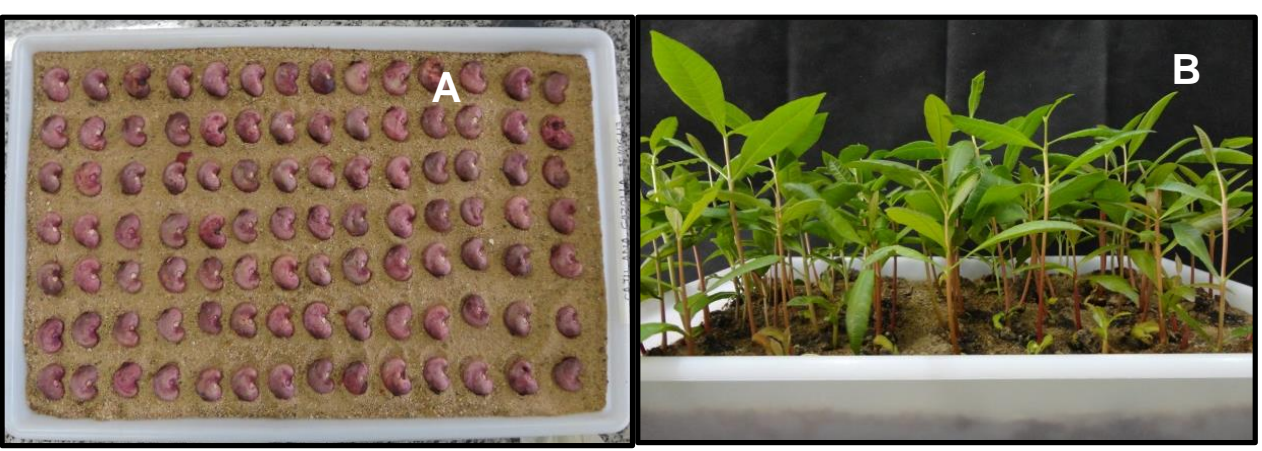

Fig 1. Sowing of A. othonianum Rizz. in plastic trays containing sand substrate (a); Seedlings of A. othonianum Rizz., 30 days after sowing (b).

Table 2. Average length of the aerial parts and average number of expanded leaves of A. othonianum Rizz. seedlings after different treatment periods.

\begin{tabular}{lll}
\hline Evaluation period (days) & $\begin{array}{l}\text { Average length of the aerial parts } \\
(\mathrm{cm})\end{array}$ & $\begin{array}{l}\text { Average number of expanded } \\
\text { leaves }\end{array}$ \\
\hline 0 & $3.82^{\mathrm{z}} \mathrm{C}$ & \\
20 & $4.89 \mathrm{~B}$ & $1.69 \mathrm{~B}$ \\
40 & $5.54 \mathrm{~A}$ & $2.46 \mathrm{~A}$ \\
\hline
\end{tabular}

${ }^{\mathrm{z}}$ Means followed by the same letter did not statistically differ using Tukey's test $(\mathrm{p} \leq 0.05)$.

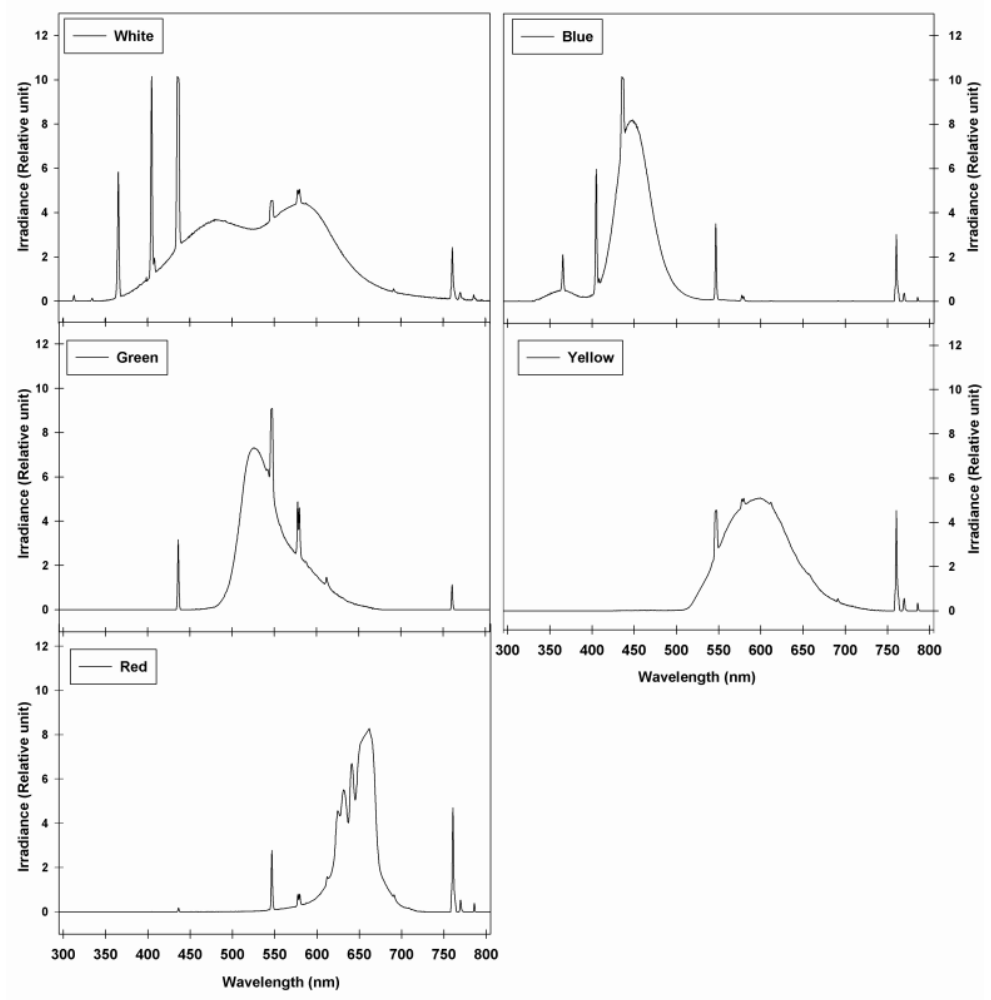

Fig 2. Spectral characteristics of the fluorescent lights used in the treatments. 
Table 3. Accumulation of fresh and dry weights of A. othonianum Rizz. seedlings after 40 days of exposure to different light spectra.

\begin{tabular}{lcc}
\hline Treatment & FW $(\mathrm{mg})$ & DW $(\mathrm{mg})$ \\
\hline White light & $300.4 \mathrm{~b}^{\mathrm{z}} \pm 0.101$ & $71.0 \mathrm{~b} \pm 0.019$ \\
Blue light & $310.2 \mathrm{~b} \pm 0.069$ & $72.5 \mathrm{~b} \pm 0.018$ \\
Green light & $318.4 \mathrm{~b} \pm 0.069$ & $82.8 \mathrm{~b} \pm 0.016$ \\
Red light & $325.5 \mathrm{a} \pm 0.034$ & $83.3 \mathrm{a} \pm 0.012$ \\
Light yellow & $335.1 \mathrm{a} \pm 0.026$ & $84.5 \mathrm{a} \pm 0.080$ \\
\hline Means followed by the same letter did not differ statistically using Tukey's test $(\mathrm{p} \leq 0.05) . \mathrm{FW}=$ fresh weight; $\mathrm{DW}=$ dry weight; $\mathrm{mg}=$ milligrams.
\end{tabular}

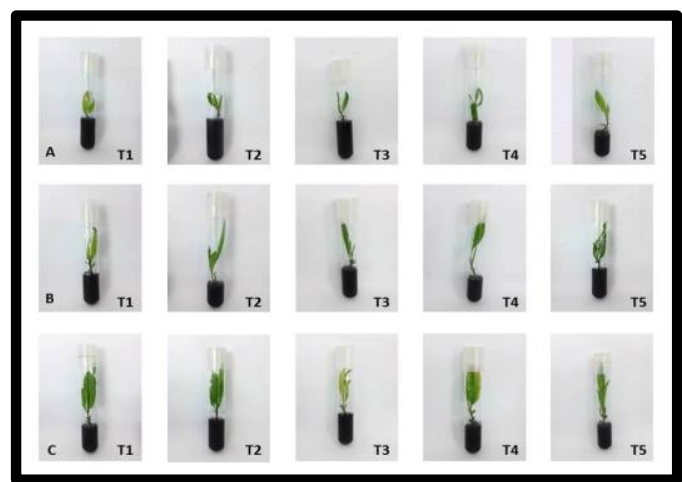

Fig 3. Growth of A. othonianum Rizz. Seedlings after 0 (A), 20 (B), and 40 (C) days cultured under different light spectra: (T1) white,(T2) blue, (T3) green, (T4) red, (T5) yellow.

A

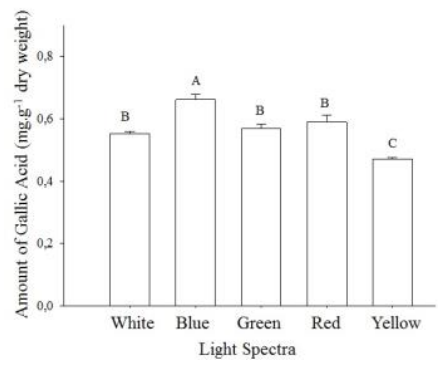

$\mathrm{C}$

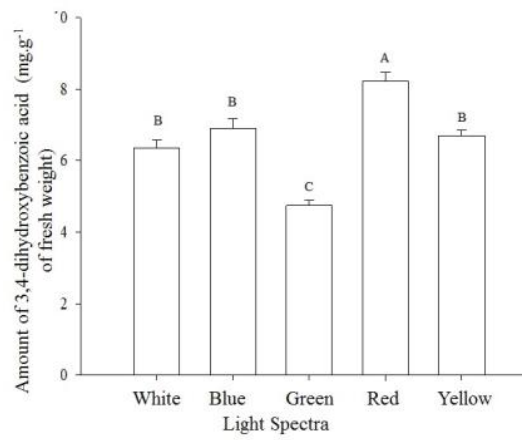

$\mathrm{E}$

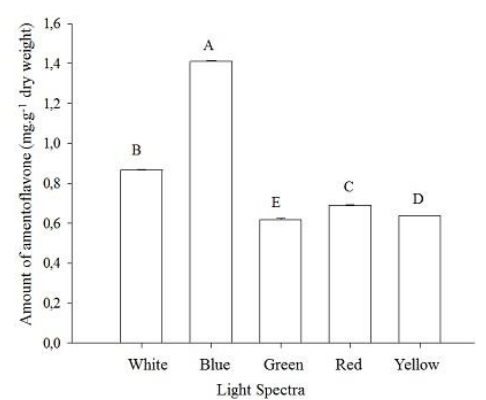

B

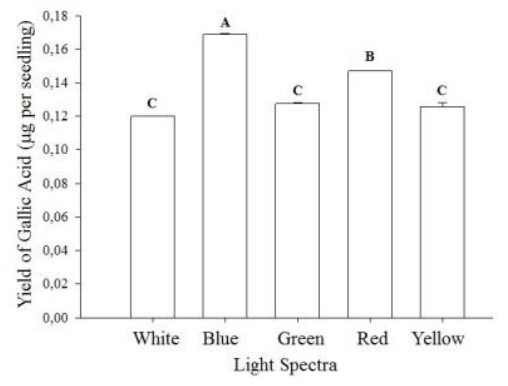

$\mathrm{D}$

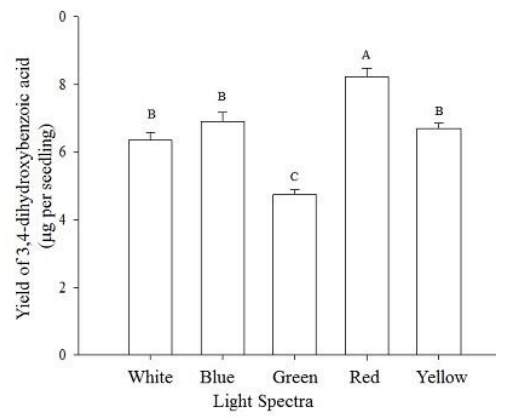

$\mathrm{F}$

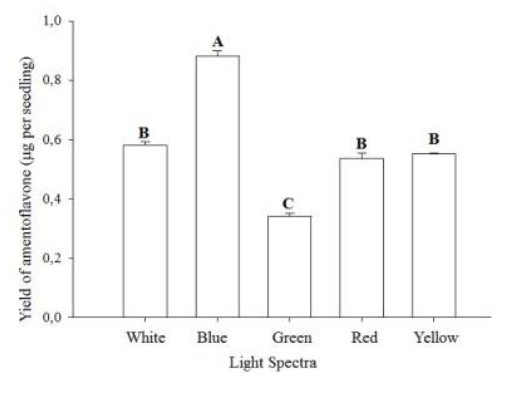

Fig 4. Concentrations and yields of gallic acid (A and B), 3,4-dihydroxybenzoic acid (C and D), and amentoflavone (E and $\mathrm{F})$ in $A$. othonianum Rizz. seedlings grown under different light spectra. DW = dry weight. Identical letters indicate that no significant difference was found using Tukey's test at a significance level of 5\%. *Vertical bars represent the standard error of the mean of the triplicates. 
yellow and red light. However, green light produced the lowest concentrations of the evaluated phytochemicals, with less beneficial effects (Liu, 2012). Johkan et al. (2012) evaluated the growth of lettuce under green light and found that at high light intensity, green light can stimulate the phenylpropanoid pathway.

Our results demonstrate that red light was more effective in stimulating 3,4-dihydroxybenzoic acid (protocatechuic acid) synthesis. On the other hand, gallic acid and the biflavonoid amentoflavone accumulated more efficiently under blue light. Both white and blue lights are equally beneficial to the total production of phenolic acids in in vitro cultures of Ruta graveolens and $R$. divaricata. Blue light is generally known to induce phenol synthesis in plants (Szopa et al., 2012). Although gallic acid and 3,4-dihydroxybenzoic acid belong to the same chemical substance class (phenolic C6C1 compounds). In this study, their responses to light were differed. This finding was also observed in Betula pendula seedlings by Tegelberg et al. (2004). An alternative biosynthetic pathway for the formation of gallic and 3,4dihydroxibenzoic acid involves the precursor of shikimic acid, 3-dehydroshikimic acid. However, 3,4-dihydroxibenzoic acid can be simultaneously converted to gallic acid, which explains its low yield in contrast to the increase of gallic acid observed under blue light (Mustafa and Verpoorte, 2007).

Phenylalanine ammonia-lyase $(P A L)$ and Chalcone synthase $(C H S)$ are important regulatory enzymes for the biosynthesis of phenylpropanoids (C6C3 compounds), which are the precursors of other phenolic compounds such as flavonoids. Molecular studies have revealed that CHS expression levels vary according to the type of incident light used for plants. Thus, flavonoid content may also vary in this manner (Mustafa and Verpoorte, 2007; Tegelberg et al., 2004; Wade et al., 2001).

PAL is involved in the response of plants to a variety of biotic and abiotic stressors (Wang et al., 2010, Yousefzadi et al., 2012). In plants, light acts upon a complex system involving several photoreceptors including UV, blue, phytochrome and the photosynthetic system. Thus, light is one of the most important factors for the control of flavonoid synthesis. A recent study of Cyclopia subternata callus cultures cultivated under various light conditions showed that blue light resulted in the highest levels of the flavonoid hesperidin and the isoflavones 7-O- $\beta$-glucosides (Kokotkiewicz et al., 2014). The enhanced concentration of the flavonoid amentoflavone under blue light found in the present study is in agreement with several researchers (Awad et al., 2001; Tegelberg et al., 2004), indicating that blue light has a beneficial effect on the accumulation of flavonoids in in vitro cultures.

\section{Materials and Methods}

\section{Plant material and in vitro cultivation}

The in vitro seedlings were established from A. othonianum seeds at the Plant Tissue Culture Laboratory of the Federal Institute of Education, Science and Technology of Goiás, Rio Verde campus, state of Goiás, Brazil. The seeds were collected from fruit trees native to the region of Montes Claros de Goiás $\left(16^{\circ} 10^{\prime} 8 " \mathrm{~S}, 51^{\circ} 27^{\prime} 12^{\prime \prime} \mathrm{W}, 412 \mathrm{~m}\right.$ altitude). Voucher number 3793 has been deposited into the Jataiense Herbarium at the Federal University of Goiás, Jataí.

After the seeds were collected, they were pulped, washed, dried, and treated with the fungicide Vitavax-Thiram ${ }^{\circledR}$ [active ingredients: carboxin and tetramethylthiuram disulfide at 200 g. $\mathrm{L}^{-1}$ and $200 \mathrm{~g} . \mathrm{L}^{-1}$, respectively] at a dose of $300 \mathrm{~mL}$ per 100 $\mathrm{kg}$ seed, and they were subsequently stored in a cold room $\left(18 \pm 3^{\circ} \mathrm{C}\right)$ until sowing.

Germination was performed in plastic trays $(53 \times 37 \times 8$ $\mathrm{cm}$ ) containing a substrate of coarse sand (washed and sieved, Fig 1), which were maintained in a growth room at an average temperature of $25 \pm 3^{\circ} \mathrm{C}$. Phytosanitary control of the seedlings was performed by spraying them with a systemic fungicide solution of $0.2 \%$ Derosal ${ }^{\circledR}$. The seedlings were irrigated biweekly with a nutrient solution containing $50 \%$ of the salts in MS medium (Murashige and Skoog 1962). After 30 days of sowing, the nodal segments were collected and used as the explant source for the experiments. The seedlings were sprayed with $0.2 \%$ Derosal $\AA$, a systemic fungicide, 12 hours before the collection of the nodal segments. After collection, the nodal segments were kept in containers with tap water and three drops of mild detergent for $30 \mathrm{~min}$. Subsequently, they were immersed in $70 \%$ ethanol $(\mathrm{v} / \mathrm{v})$ for $30 \mathrm{~s}$ and $20 \%$ sodium hypochlorite for $20 \mathrm{~min}$. They were then washed in triplicate with distilled water under a laminar flow hood and autoclaved. Nodal segments with a length of approximately $2 \mathrm{~cm}$ containing two buds were inoculated into test tubes containing $20 \mathrm{~mL}$ of the culture medium, which consisted of MS with a 50\% concentration of salts (MS 50\%) supplemented with $30 \mathrm{~g} . \mathrm{L}^{-1}$ of sucrose, $3.5 \mathrm{~g} . \mathrm{L}^{-1}$ of agar, 2 g. $\mathrm{L}^{-1}$ of activated charcoal, and $30 \mu \mathrm{M}$ of 6 benzylaminopurine (BAP). The $\mathrm{pH}$ was adjusted to $5.8 \pm 0.3$ prior to the addition of the gelling agent, and the culture medium was autoclaved at $120^{\circ} \mathrm{C}$ for $20 \mathrm{~min}$. Inoculated tubes, containing one explant each, were maintained in a growth room under a 16-h photoperiod at a temperature of 25 $\pm 3^{\circ} \mathrm{C}$ for 30 days, using the methodology of Assis et al. (2011). To increase the number of shoots, the in vitro seedlings were subcultured after 30 days using the same type of culture medium. Three subcultures were performed to obtain a sufficient number of seedlings for use in the experiments.

\section{Light conditions}

The seedlings were subcultured and grown under identical culture conditions for 15 days, and then, they were transferred in to the environments with either white $(300-750$ $\mathrm{nm})$, blue $(400-490 \mathrm{~nm})$, green $(490-560 \mathrm{~nm})$ red $(600-700$ $\mathrm{nm}$ ), or yellow light $(560-590 \mathrm{~nm}$ ) (Fig 2) using $40 \mathrm{~W}$ Taschibra ${ }^{\circledR}$ fluorescent lamps (Indaial, Santa Catarina, Brazil) at an irradiance of $50 \pm 5 \mu \mathrm{mol} \cdot \mathrm{m}^{2} \cdot \mathrm{s}^{-1}$ under a 16-h photoperiod. Spectral quality was determined using a USB2000 spectroradiometer (Ocean Optics, Dunedin, FL, USA), and the light intensity was adjusted using a PAR sensor (QSO-S model; Decagon Devices, Pullman, WA, USA). The seedlings were maintained in this manner for 40 days. The light chambers were sealed using a black cloth to avoid light interference. The number of expanded leaves and the length of the aerial parts of the seedlings were evaluated after 20 and 40 days of exposure, and their fresh and dry weights were evaluated after 40 days of exposure.

\section{Chemical analysi}

The gallic acid, 3,4-dihydroxybenzoic acid, and amentoflavone standards, isolated from A. othonianum Rizz. leaves in the field by the natural products research group of UNIFRAN (Curado et al., 2016), were used to obtain a calibration curve. For quantitative analysis, solutions of each standard were prepared using HPLC-grade methanol to obtain concentrations of $0.25,0.125,0.0625$, and 0.00625 
mg.mL $L^{-1}$, and these solvents were injected in triplicate for high performance liquid chromatography (HPLC).

The HPLC analyses were performed using a binary solvent system in a SHIMADZU LC-20AD-Prominence instrument equipped with a SIL-20A HT auto sampler coupled to a SPDM20A UV-VIS detector with a diode array. The GEMINI Phenomenex $\mathrm{C}_{18}$ phase $(250 \times 4.6 \mathrm{~mm}, 5 \mu \mathrm{m})$ analytical column was equipped with a precolumn of identical material and a CTO-20A column oven. The injected volume was 20 $\mu \mathrm{L}$, the flow rate was $1 \mathrm{~mL} \cdot \mathrm{min}^{-1}$, and $\lambda$ was $254 \mathrm{~nm}$. The temperature was maintained at $40^{\circ} \mathrm{C}$. The analyses were performed over $60 \mathrm{~min}$, and elution was performed using the following linear gradient: $\mathrm{CH}_{3} \mathrm{OH} / \mathrm{H}_{2} \mathrm{O} / \mathrm{CH}_{3} \mathrm{COOH}$ (ratio of 5.0:94.9:0.1 v/v/v), $100 \% \mathrm{CH}_{3} \mathrm{OH}$ for $30 \mathrm{~min}, 100 \% \mathrm{MeOH}$ for $10 \mathrm{~min}$, and $20 \mathrm{~min}$ to return to baseline conditions. The solvents used were HPLC-grade methanol and $0.1 \%$ acetic acid prepared in Milli-Q water. Data acquisition was performed using a computer.

\section{Sample preparation for HPLC analysis}

The dried aerial parts $(200 \mathrm{mg})$ of the A. othonianum Rizz. seedlings cultured in vitro were extracted in $4 \mathrm{~mL}$ of HPLCgrade methanol using an ultrasound bath for $30 \mathrm{~min}$. After filtration with Advantec HP020AN membranes $(20-\mu \mathrm{m}$ mesh), the seedlings were transferred to $1-\mathrm{mL}$ vials and were analyzed by HPLC in triplicate. To calculate the yield, the average amount of dry weight per seedling was multiplied by the content of each measured compound.

\section{Experimental design}

For the growth variables (length of the aerial parts and number of leaves), the experimental design was completely randomized using a $5 \times 3$ factorial arrangement (5 types of light sources $\mathrm{x} 3$ periods of evaluation), and each treatment was applied in quadruplicate using a total of 20 test tubes. For the calculation of the fresh and dry weights, 5 types of light sources and 1 period of evaluation (40 days) were used. The samples were prepared in triplicate for chemical analysis. The numerical data were statistically evaluated via analysis of variance (ANOVA), and the means were tested using Tukey's test at a significance level of 5\% using SISVAR software (Ferreira 2011).

\section{Conclusion}

The spectral quality of light influenced the biomass and phenolic acid and biflavonoid levels of A. othonianum Rizz. seedlings in vitro. Red and yellow light stimulated the accumulation of dry weight in A. othonianum Rizz. seedlings. The levels and yields of gallic acid and amentoflavone increased in the presence of blue light. In contrast, the red light promoted the production of 3,4-dihydroxybenzoic acid. Research on light quality and the accumulation of secondary metabolites in in vitro cultures has great potential for directing the production of interesting compounds.

\section{Acknowledgments}

The authors would like to thank the Brazilian Federal Agency for the Support and Evaluation of Graduate Education (Coordenação de Aperfeiçoamento de Pessoal de Nível Superior - CNPq) (Grant \# 305783/2012-2 and the São Paulo Research Foundation (Fundação de Amparo à Pesquisa do Estado de São Paulo - FAPESP) (Grant \# 2011/00631-5).

\section{References}

Agostini-Costa TS, Faria JP, Naves RV, Vieira RF (2006) Cajus do Cerrado. In: Vieira RF, Agostini-Costa TDS, Silva DB, Ferreira FR, Sano SM (eds) Frutas nativas da região centro-oeste do Brasil. Recursos Genéticos e Biotecnologia, Embrapa, Brasília, pp 136-151.

Assis KC, Pereira FD, Santos SC, Silva FG, Silva AF, Menezes CCE (2011) Rendimento de explantes e estabelecimento in vitro de segmentos nodais de Anacardium othonianum Rizz., oriundos de sementes armazenadas por diferentes períodos. Global Sci Technol. 4(1):1-7.

Awad MA, Wagenmakers PS, De Jager A (2001) Effects of light on flavonoid and chlorogenic acid levels in the skin of 'Jonagold' apples. Sci Hort. 88(4):289-298.

Bessa LA, Silva FG, Moreira MA, Teodoro JPR, Soares FAL (2013)Growth and nutrient accumulation of Anacardium othonianum Rizz seedlings grown in nutrient solution. Chilean J Agric Res. 73 (3), 301-308.

Bian ZH, Yang QC, Liu WK (2015) Effects of light quality on the accumulation of phytochemicals in vegetables produced in controlled environments: a review. J Sci Food Agric. 95: 869-877.

Carvalho SD, Folta KM (2014) Sequential light programs shape kale (Brassica napus) sprout appearance and alter metabolic and nutrient content. Hort Res. 1:8.

Curado FMLMJ, Gazolla AP, Pedroso RCN, Pimenta LP, Oliveira PF, Tavares DC, Silva MLA, Cunha WR, Pietro RCLR, Januário AH, Pauletti PM, Sales JF, Silva FG (2016) Antifungal and cytotoxicity activities of Anacardium othonianum extract. J. Med. Plants Res.10(29):450-456.

Faria PSA, Senábio JA, Soares MA, Silva FG, Cunha APA, Souchie EL (2016) Assessment of functional traits in the assemblage of endophytic fungi of Anacardium othonianum Rizzini. Pak J Bot. 48(3): 1241-1252.

Ferreira DF (2011) Sisvar: a computer statistical analysis system. Ciênc Agrotec. 35(6): 1039-1042.

Folta KM, Childers KS (2008) Light as a growth regulator: controlling plant biology with narrow-bandwidth solid-state lighting systems. Hort Sci. 43(7):1957-1964.

Jeong GT, Woo JC, Park DH (2007) Effect of plant growth regulators on growth and biosynthesis of phenolic compounds in genetically transformed hairy roots of Panax ginseng C.A. Meyer. Biotechnol Bioprocess Eng. 12(2):8691.

Johkan M, Shoji K, Goto F, Hahida S, Yoshihara T (2012) Effect of green light wavelength and intensity on photomorphogenesis and photosynthesis in Lactuca sativa. Environ Exp Bot. 75:128-133.

Kokotkiewicz A, Bucinski A, Luczkiewicz M (2014) Light and temperature conditions affect bioflavonoid accumulation in callus cultures of Cyclopia subternata Vogel (honeybush). Plant Cell Tis Organ Cult. 118(3):589593.

Kvaalen H, Appelgren M (1999) Light quality influences germination, root growth and hypocotyl elongation in somatic embryos but not in seedlings of Norway spruce. In Vitro Cell Dev Biol-Plant. 35(6):437-441.

Lee EJ, Kim MK, Paek KY (2010) Auxin and cytokinin affect biomass and bioactive compound production from adventitious roots of Eleutherococcus koreanum. J Hort Sci Technol. 28:678-684.

Liu W (2012) Light environmental management for artificial protected horticulture. Agrotechnol. 1:101. 
Macedo AF, Leal-Costa MV, Tavares ES, Lage CLS, Esquibel MA (2011) The effect of light quality on leaf production and development of in vitro-cultured plants of Alternanthera brasiliana Kuntze. Environ Exp Bot. 70(1):43-50.

Murashige T, Skoog F (1962) A revised medium for a rapid growth and bio assays with tobacco tissue cultures. Physiol Plant. 15(3):473-479.

Mustafa NR, Verpoorte R (2007) Phenolic compounds in Catharanthus roseus. Phytochem Rev. 6(2):243-258.

Nishimura T, Zobayed SMA, Kozai T, Goto E (2007) Medicinally important secondary metabolites and growth of Hypericum perforatum L. Plants affected by light quality and intensity. Environ Control Biol. 45(2):113-120.

Odabas MS, Radugienë JR, Camas N, Valdimaras J, Ivanauskas L, Çirak C (2009) The quantitative effects of temperature and light intensity on hyperforin and hypericins accumulation in Hypericum perforatum L. J Med Plants Res. 3(7):519-525.

Silva DB, Silva JA, Junqueira NTV, Andrade LRM (2001) Frutas do cerrado. Embrapa, Brasília, Informação Tecnológica, 179p.

Silva MR, Lacerda DBCL, Santos GG, Martins DMO (2008) Chemical characterization of native species of fruits from savanna ecosystem. Ciên Rur. 8: 1790-1793.

Szopa A, Ekiert H, Szewczyk A, Fugas E (2012) Production of bioactive phenolic acids and furanocoumarins in in vitro cultures of Ruta graveolens L. and Ruta graveolensssp. divaricata (Tenore) Gams. under different light conditions. Plant Cell Tis Organ Cult. 110(3):329-336

Tegelberg R, Julkunen-Tiitto R, Aphalo PJ (2004) Red: farred light ratio and UV-B radiation: their effects on leaf phenolics and growth of silver birch seedlings. Plant Cell Environ. 27(8):1005-1013.
Victório CP, Leal-Costa MV, Tavares ES, Kuster RM, Lage CLS (2015) Light spectral affect the morphoanatomical and chemicals features of clonal Phyllantus tenellus Roxb. grown in vitro. J Med Plants Res. 9(5):111-121.

Vieira RF, Agostini-Costa TS,Silva DB, Ferreira FR, Sano SM(2006) Frutas nativas da região Centro-Oeste do Brasil. Recursos Genéticos e Biotecnologia, Brasília, 320p.

Vreugdenhil D, Boogaard Y, Visser RGF, De Bruijn SM (1998) Comparison of tuber and shoot formation from in vitro cultured potato explants. Plant Cell Tis Organ Cult. 53(3):197-204.

Wade HK, Bibikova TN, Valentine WJ, Jenkins GI (2001) Interactions within a network of phytochrome, cryptochrome and UV-B phototransduction pathways regulate chalcone synthase gene expression in Arabidopsis leaf tissue. Plant J. 25(6):675-685.

Wang Y, Zhang H, Zhao B, Yuan X (2001) Improved growth os Artemisia annua L. Hairy roots and artemisin production under red light condictions. Biotechnol Lett. 23(23):19711973.

Wang H, Jiang YP, Yu HJ, Xia XJ, Shi K, Zhou YH, Yu JQ (2010) Light quality affects incidence of powdery mildew, expression of defence-related genes and associated metabolism in cucumber plants. Eur J Plant Pathol. 127(1):125-135.

Wang Y, Gao L, Wang Z, Liu Y, Sun M, Yang D, Wei C, Shan Y, Xia T (2012) Light-induced expression of genes involved in phenylpropanoid biosynthetic pathways in callus of tea (Camellia sinensis (L.) O Kuntze). Sci Hort.133:72-83.

Yousefzadi M, Sharifi M, Behmanesh M, Ghasempour A, Moyano E, Palazon J (2012) The effect of light on gene expression and podophyllotoxin biosynthesis in Linum album cell culture. Plant Physiol Biochem. 56:41-46. 